\title{
Acceptability of the human papilloma virus vaccine among Moroccan parents: a population-based cross- sectional study
}

F. Selmouni, ${ }^{1,2}$ A. Zidouh, ${ }^{3}$ C. Nejjari ${ }^{4}$ and R. Bekkali ${ }^{3}$

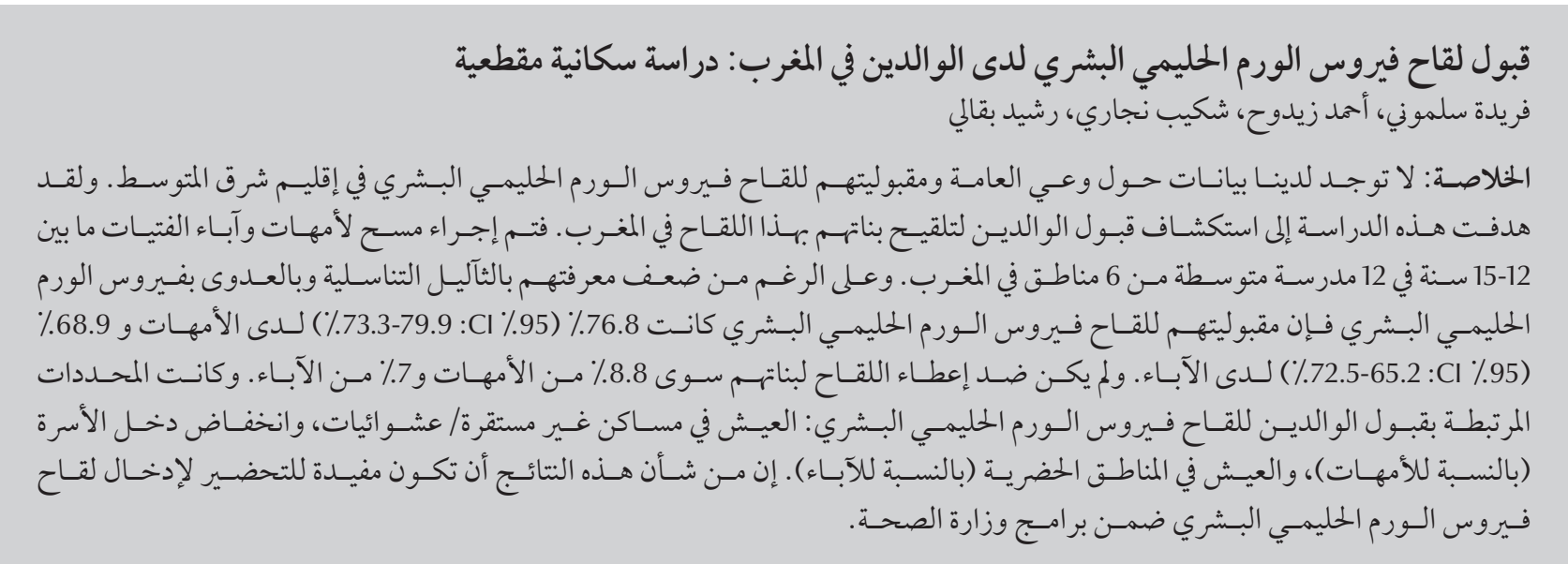

ABSTRACT Data about the public's awareness and acceptability of the human papilloma virus (HPV) vaccine are lacking in the Eastern Mediterranean Region. This study aimed to explore parental acceptability of HPV vaccination for their daughters in Morocco. A cross-sectional survey was carried out among mothers and fathers of girls aged 12-15 years at 12 middle schools from 6 regions of Morocco. Despite weak knowledge of genital warts and HPV infection, acceptability of the HPV vaccine was 76.8\% (95\% Cl: $73.3-79.9 \%$ ) among mothers and $68.9 \%$ (95\% Cl: $65.2-72.5 \%)$ among fathers. Only $8.8 \%$ of mothers and $7.0 \%$ of fathers were against administration of the HPV vaccine to their daughters. Predictors of parents' acceptance of the HPV vaccine were living in precarious housing/slums and low household income (for mothers) and living in urban areas (for fathers). These results will be useful for preparing the introduction of the HPV vaccine in health ministry programmes.

Acceptabilité du vaccin contre le papillomavirus humain chez des parents marocains : étude populationnelle transversale

RÉSUMÉ Les données sur les connaissances relatives au vaccin contre le papillomavirus humain et son acceptabilité par le public sont rares dans la Région de la Méditerranée orientale. La présente étude visait à évaluer l'acceptabilité de la vaccination des filles contre le papillomavirus humain pour leurs parents au Maroc. Une étude transversale a été menée chez les mères et les pères de filles âgées de 12 à 15 ans dans 12 collèges situés dans six régions du Maroc. En dépit de faibles connaissances concernant les verrues génitales et l'infection par le papillomavirus humain, I'acceptabilité du vaccin contre le papillomavirus humain était de 76,8 \% (IC à 95\% : 73,3 - 79,9 \%) chez les mères et de 68,9 \% (IC à $95 \%$ : 65,2 - 72,5\%) chez les pères. Seuls 8,8 \% des mères et 7,0 \% des pères étaient opposés à l'administration du vaccin contre le papillomavirus humain à leur(s) fille(s). Vivre dans des logements insalubres/des bidonvilles et avoir un revenu du ménage faible pour les mères, et vivre en zone urbaine pour les pères étaient des facteurs prédictifs de l'acceptation du vaccin contre le papillomavirus humain. Ces résultats seront utiles pour préparer l'introduction du vaccin contre le papillomavirus humain dans les programmes du ministère de la santé.

'Complutense University of Madrid, Madrid, Spain (Correspondence to F. Selmouni: faridaselmouni@gmail.com). ${ }^{2}$ Higher Institute of Nursing Professions and Techniques of Health of Rabat, Rabat, Morocco. ${ }^{3}$ Lalla Salma Foundation, Cancer Prevention and Treatment, Rabat, Morocco. ${ }^{4}$ National School of Public Health, Rabat, Morocco.

Received: 25/01/15; accepted: 02/06/15 


\section{Introduction}

In Morocco, cervical cancer represents $13.3 \%$ of all women's cancers and is the second most common cancer among women after breast cancer (1). The standardized incidence of cervical cancer was 14.6 in 2007 (1), with approximately 2258 new cases occurring in 2012 (2). In the absence of a screening programme, $70-80 \%$ of reported cases of cervical cancer in Morocco are diagnosed and managed at advanced stages (3). The persistence of human papilloma virus (HPV) infection, especially HPV types 16 and 18 , is the main cause of cervical cancer in Moroccan women $(3,4)$. Other factors such as high parity, low educational level, multiple sexual partners, intercourse during menstruation and history of sexually transmitted infection (STI) have also been identified as factors associated with cervical cancer in Morocco (3).

Currently, 2 types of vaccine (the tetravalent vaccine against HPV 6, 11, 16 and 18 , and the bivalent vaccine against HPV 16 and 18) have been introduced into the immunization schedule in many developed and some developing countries. The prophylactic potential of both vaccines has been demonstrated by several clinical trials recognized for their scientific rigour; these vaccines prevent almost $100 \%$ of persistent HPV cervical infections, cervical dysplasia (CIN 2 and 3 ) and in situ adenocarcinoma (5-8). They can also prevent vulvar intraepithelial neoplasia (VIN 2/3), vaginal intraepithelial neoplasia (Va IN 2/3) and condylomata acuminate associated with HPV 6 and 11 (9-11). The HPV vaccine is highly immunogenic, safe and effective for preventing HPV 16 and 18 infections and related precancerous lesions. The $\mathrm{HPV}$ vaccine is very promising, even in the absence of sound evidence of a real reduction in the incidence of cervical cancer $(10,11)$.

There is a contentious debate, however, about the appropriate age of administration of HPV vaccine, the duration of protection, vaccine side-effects and the indications for males. Sociocultural and religious beliefs, as well as socioeconomic status, seem to be barriers to positive attitudes of parents toward the HPV vaccine $(12,13)$. Data from different studies reported that parents had low levels of awareness of HPV, but that the acceptability of the HPV vaccine was higher (14-16). These studies were conducted in different contexts, but none of them focused on countries in the World Health Organization's Eastern Mediterranean Region. To our knowledge, until 2011, there have been no data available in the Region on the knowledge of the population about the causes and prevention of STI or cervical cancer.

The aims of this study were to determine the knowledge of Moroccan mothers and fathers about some STIs, HPV infection, cervical cancer and the Papanicolaou (Pap) smear test, and to explore parental acceptability of HPV vaccination for their daughters. To our knowledge, there no similar study has previously been conducted in Morocco.

\section{Methods}

\section{Study design and sample}

To explore HPV vaccine acceptability of parents, 2 cross-sectional surveys were carried out independently among mothers and among fathers of girls at middle school ( $12-15$ years of age) in 2011. Our main concern was to choose carefully the best representative sample of the Moroccan population in terms of geographical, cultural and socioeconomic characteristics. Thus, we made a purposeful choice of 6 regions of Morocco: northern, southern, eastern, western, central-north and central-south.

To get separate samples of mothers and fathers, through the selection of their daughters, 2 separate sets of 2 middle schools were selected at random in each region, 1 middle school from the large cities of the region and 1 from smaller towns. Thus, we obtained 12 middle schools for the sample of mothers and 12 middle schools for the sample of fathers. In each middle school, 1 class was randomly selected from each of the 3 school levels (1st, 2nd and 3rd levels). Parents of girls of the selected 36 classes were enrolled in the study samples. Given that in Morocco the average number of girls per class in middle schools is about 15 girls, we expected to have an acceptable sample size of 540 mothers and 540 fathers.

\section{Data collection}

Face-to-face interviews were carried out at the parents' homes by trained interviewers, from February to March 2011. Female interviewers administered the questionnaire to the mothers, and male interviewers administered the questionnaire to the fathers. To ensure comprehension and validation of the questionnaire a pilot study was conducted during the interviewers' training in an area excluded from the study sample.

The questionnaire addressed demographic data, then knowledge of some STIs and HPV infection, followed by awareness about cervical cancer risk factors and prevention and the Pap smear test. After that, interviewers provided parents verbally with basic information on HPV infection, its prevention and complications. Then they asked them about their attitudes to the HPV vaccination, their willingness to immunize their daughters and their reasons for accepting or not.

The anonymity of the collected data was assured, as well as free consent to participate in the interview. The study protocol and questionnaire were approved by the ethics committee of University of Fez Hospital, Fez, Morocco.

\section{Data analysis}

The statistical analysis was carried out using Epi Info 2000 and SPSS, version 
17. Univariate and multivariate analysis were used to describe HPV acceptance and related factors. Descriptive analysis was used to define demographic data and the relative frequencies of knowledge of both groups. Univariate analysis was used to research associations between population characteristics and parents' knowledge about the studied infections and prevention methods; knowledge about cervical cancer, its risk factors and prevention methods; and acceptability of the HPV vaccine. Regression models were used to determine the most explanatory variables associated with the acceptability of the HPV vaccine, knowledge of cervical cancer and risk factors and prevention, adjusting for potential confounding factors. Differences were considered statistically significant at $P$-value $<0.05$.

\section{Results}

\section{Awareness and acceptability of the HPV vaccine by mothers}

Among the mothers of the 667 selected girls, 653 mothers consented to participate in the survey; the response rate was $97.9 \%$. The mean age of mothers was 41.8 [standard deviation (SD) 6.9] years (median 41 years; mode 40 years). More than half of mothers (58.4\%) reported that they had never attended school, while $15.3 \%$ and $3.7 \%$ had secondary school and university level education respectively. Half (49.3\%) stated that the total household income was $<2000$ Moroccan dirham (MAD) per month and $62.7 \%$ had no medical coverage (Table 1).

Only 19.2\% (95\% CI: 16.3-22.5\%) of mothers had heard of condyloma, but $47.5 \%$ of them had heard about genital warts and knew that warts were transmitted sexually. The vast majority (91.0\%) had no prior knowledge about HPV infection, while $84.7 \%$ (95\% CI: 81.6$87.3 \%$ ) of them had heard of cervical cancer (Table 1). The main preventive measure of cervical cancer reported by mothers was the cervical Pap smear (36.5\% of mothers), HPV vaccination (24.4\%) and condom use (24.0\%). Almost 1 in 3 mothers (31.9\%) knew about the smear test and $37.6 \%$ of them had done the test at least once.

Acceptability of the HPV vaccine was $76.8 \%$ (95\% CI: $73.3-79.9 \%$ ) among mothers (36.7\% strongly agree and $40.1 \%$ agree); only $8.8 \%$ rejected the idea that the HPV vaccine be administered to their daughters, while $14.4 \%$ of mothers were still undecided (Table 1). Among mothers, $76.0 \%$ wanted the HPV vaccine to be available for girls aged $13-18$ years, and only $12.1 \%$ of the mothers thought that the HPV vaccine should be prescribed at age 10-12 years. For the great majority of mothers (89.0\%), the price of the HPV vaccine should be $<200$ MAD to be reasonably priced.

The main reasons given by mothers who agreed that their daughters receive the HPV vaccine were cervical cancer prevention and the well-being of their daughters ( $95 \%$ of cases, $n=487$ ); for $3 \%$ of mothers the reasons were the vaccines efficacy and safety. For mothers who refused administration of the HPV vaccine to their daughters, their main reasons were the side-effects of the vaccine and their lack of knowledge about the vaccine. Arguments that could change the opinions of these mothers were guarantees about the absence of side-effects of the vaccine and the agreement of the father $(60 \%, n=35)$.

\section{Awareness and acceptability of the HPV vaccine by fathers}

Among the fathers of 672 selected girls, 659 fathers consented to participate in the survey; the response rate was $98.1 \%$. The mean age of fathers was 49.3 (SD 8.2) years (median 49 years; mode 50 years). More than 1 in 5 fathers (21.7\%) had never attended school; nearly 3 in 10 fathers had secondary education and 1 in 6 fathers had university level education. More than one-third of fathers (36.2\%) reported that the household had a monthly income < 2000 MAD and less than half of the households had no medical coverage (Table 1 ).

One-fifth of fathers $(20.4 \%$; $95 \%$ CI: $17.5-23.7 \%)$ had heard of condyloma and only $6.6 \%$ (95\% CI: 4.9-8.9\%) had ever heard of HPV infection, while $60.1 \%$ (95\% CI: 56.3-63.9\%) of them had heard of cervical cancer (Table 1). One-third of fathers reported that the main preventive measures for cervical cancer were the Pap smear, condoms and $H P V$ vaccination.

Acceptability of the HPV vaccine was $68.9 \%$ (95\% CI: $65.2-72.5 \%$ ) among fathers (23.2\% strongly agree and $45.7 \%$ agree); only $7.0 \%$ refused to have the HPV vaccine administered to their daughters, while $24.1 \%$ of fathers were undecided (Table 1). The HPV vaccine should be prescribed for girls before the age of 10 years according to $15 \%$ of fathers, between $13-18$ years for $75.0 \%$, and only $8.0 \%$ of fathers thought that the HPV vaccine should be administered at age 10-12 years. The great majority of fathers $(89.0 \%)$ who agreed to have their daughters vaccinated stated that the vaccine price should be $<200 \mathrm{MAD}$.

The main reasons given by fathers who agreed that their daughters receive the HPV vaccine were cervical cancer prevention and the well-being of their daughters ( $94 \%$ of cases, $n=443$ ); for $1 \%$ of fathers the reasons were the efficacy and safety of the vaccine. However, for fathers who refused to accept the HPV vaccine for their daughters, their main reasons were the side-effects of the vaccine and lack of knowledge about the vaccine. The arguments that could change their opinion were guarantees about the absence of side-effects and proof of the effectiveness of the vaccine.

\section{Comparison of data for mothers and father}

The mothers knew more about cervical cancer [prevalence ratio $(\mathrm{PR})=1.41$ ] and the Pap smear $(P R=1.62)$ than did fathers and these differences were 


\begin{tabular}{|c|c|c|c|c|}
\hline \multirow{2}{*}{$\begin{array}{l}\text { Variable } \\
\text { Age group (years) [Mean (SD)] }\end{array}$} & \multicolumn{2}{|c|}{ Mothers $(n=653)^{\text {a }}$} & \multicolumn{2}{|c|}{ Fathers $(n=659)^{\text {a }}$} \\
\hline & 645 & $41.8(6.9)$ & 652 & $49.3(8.2)$ \\
\hline \multicolumn{5}{|l|}{ Residential area [No., \%] } \\
\hline Rural & 14 & 2.2 & 16 & 2.5 \\
\hline Suburban & 175 & 27.0 & 76 & 11.7 \\
\hline Urban & 460 & 70.9 & 558 & 85.8 \\
\hline \multicolumn{5}{|l|}{ Insurance status [No., \%] } \\
\hline No cover & 399 & 62.7 & 309 & 49.0 \\
\hline CNOPS & 142 & 22.3 & 161 & 25.5 \\
\hline CNSS & 59 & 9.3 & 95 & 15.1 \\
\hline Other & 36 & 5.7 & 66 & 10.5 \\
\hline \multicolumn{5}{|l|}{ Educational level [No., \%] } \\
\hline Illiterate & 377 & 58.4 & 141 & 21.7 \\
\hline Primary & 146 & 22.6 & 205 & 31.6 \\
\hline Secondary & 99 & 15.3 & 198 & 30.5 \\
\hline Higher/postgraduate & 24 & 3.7 & 105 & 16.2 \\
\hline \multicolumn{5}{|l|}{ No. of children [Mean (SD)] } \\
\hline Male & 633 & $1.52(1.17)$ & 620 & $1.45(1.12)$ \\
\hline Female & 640 & $2.42(1.22)$ & 640 & $2.44(1.30$ \\
\hline Total & 653 & $3.84(1.72)$ & 662 & $3.72(1.79)$ \\
\hline \multicolumn{5}{|c|}{ Monthly household income (MAD) [No., \%] } \\
\hline$<2000$ & 316 & 49.3 & 233 & 36.2 \\
\hline $2000-4000$ & 157 & 24.5 & 170 & 26.4 \\
\hline $4000-6000$ & 42 & 6.6 & 95 & 14.8 \\
\hline $6000-10000$ & 17 & 2.7 & 67 & 10.4 \\
\hline$>10000$ & 9 & 1.4 & 40 & 6.2 \\
\hline \multicolumn{5}{|l|}{ Housing category [No., \%] } \\
\hline Precarious or slum & 147 & 23.2 & 48 & 7.7 \\
\hline Medium & 451 & 71.1 & 553 & 88.2 \\
\hline Luxury & 21 & 3.3 & 26 & 4.1 \\
\hline Other & 15 & 2.4 & 26 & 4.1 \\
\hline \multicolumn{5}{|l|}{ Heard of genital warts [No., \%] } \\
\hline Yes & 125 & 19.2 & 135 & 20.4 \\
\hline No & 527 & 80.8 & 526 & 79.6 \\
\hline \multicolumn{5}{|l|}{ Heard of HPV infection [No., \%] } \\
\hline Yes & 59 & 9.0 & 44 & 6.6 \\
\hline No & 593 & 91.0 & 618 & 93.4 \\
\hline \multicolumn{5}{|l|}{ Heard of cervical cancer [No., \%] } \\
\hline Yes & 552 & 84.7 & 398 & 60.1 \\
\hline No & 100 & 15.3 & 264 & 39.9 \\
\hline \multicolumn{5}{|l|}{ Heard of Pap smear [No., \%] } \\
\hline Yes & 203 & 31.9 & $\mathrm{n} / \mathrm{a}$ & $\mathrm{n} / \mathrm{a}$ \\
\hline No & 433 & 68.1 & $\mathrm{n} / \mathrm{a}$ & $\mathrm{n} / \mathrm{a}$ \\
\hline \multicolumn{5}{|l|}{ Performed Pap smear [No., \%] } \\
\hline Yes & 76 & 37.6 & $\mathrm{n} / \mathrm{a}$ & $\mathrm{n} / \mathrm{a}$ \\
\hline No & 126 & 62.4 & $\mathrm{n} / \mathrm{a}$ & $\mathrm{n} / \mathrm{a}$ \\
\hline
\end{tabular}




\begin{tabular}{|c|c|c|c|c|}
\hline Variable & & $653)^{a}$ & & $59)^{a}$ \\
\hline Intend to accept va & & & & \\
\hline Strongly agree & 237 & 36.7 & 150 & 23.2 \\
\hline Agree & 259 & 40.1 & 296 & 45.7 \\
\hline Against & 40 & 6.2 & 33 & 5.1 \\
\hline Strongly against & 17 & 2.6 & 12 & 1.9 \\
\hline Undecided & 93 & 14.4 & 156 & 24.1 \\
\hline
\end{tabular}

${ }^{a}$ Varies according to the amount of missing data.

$S D=$ standard deviation; $M A D=$ Moroccan dirham; CNOPS = Caisse Nationale des Organismes de Prévoyance Sociale [National Fund for Social Welfare Organizations]; CNSS = Caisse National de Securite Sociale [National Social Security Fund]; n/a = not applicable.

highly significant $(P<0.001)$. The levels of acceptability to administer the vaccine to girls were not significantly different among mothers and fathers $(\mathrm{PR}=0.99 ; P=0.535)$. However, awareness of the risk of girls developing cervical cancer was more greater for mothers than for fathers ( $\mathrm{PR}=1.21 ; P$ $=0.0008$ ).

\section{Predictors of parents' intention to accept the HPV vaccine}

Regarding mothers' knowledge, medical coverage was significantly associated with mothers' awareness level of cervical cancer. There was a linear trend between knowledge of cervical cancer by mothers and the following variables: residential area (urban or rural), educational level and monthly household income (Table 2). For the level of vaccine acceptability by mothers, there was a decreasing linear trend according to the level of housing category and the level of household income. Mothers living in precarious housing or slums were more willing to have their daughters vaccinated than those living in a luxurious or medium-level residence. Mothers whose household income was low were more likely to accept the HPV vaccine than mothers whose household income was higher. There were no differences in the acceptability of HPV vaccines by mothers according to education level or the area where they lived (urban or rural) or the availability of medical coverage.
For the fathers' knowledge about cervical cancer there were strong linear trends in the level of knowledge about cervical cancer according to level of education and household income. Fathers living in urban areas were more likely to accept the HPV vaccination than those living in suburban or rural areas. There were no linear trends according to education level, monthly income or availability of medical coverage for fathers' acceptance of the HPV vaccine (Table 2).

\section{Discussion}

Knowledge of Moroccan parents was weak regarding condyloma and HPV infection and there were no significant differences between mothers and fathers regarding their knowledge about these issues. Awareness of cervical cancer was relatively high among Moroccan parents, with mothers having significantly better knowledge about cervical cancer than did fathers. Some studies performed in developed countries found high levels of awareness about HPV infection $(17,18)$, while others showed very little awareness even among women participating in screening programmes (19-21).

Despite having little information about STIs and HPV infection, parental acceptability of the HPV vaccine was high in our study. Similar results were reported by studies carried out in different countries, which have also shown relatively high parental acceptability of the HPV vaccine (12,14-16,21-24) (Figure 1). The main reasons for parents' favourable attitude towards the HPV vaccine are related to the desire to protect their daughters from cervical cancer and act for their well-being. The difference in HPV vaccine acceptability by fathers and mothers was not significant. However, significantly more mothers were aware of the risk of girls developing cervical cancer than were fathers. For parents who refused to vaccinate their daughters, the reasons were linked with the side-effects of the HPV vaccine and their lack of knowledge of the vaccine. To change their attitude, parents needed more information confirming the absence of side-effects and proving the effectiveness of the vaccine. Moroccan parents did not have any concerns about sexual transmission of HPV infection and did not share the idea that the vaccine may encourage early or unsafe sexual behaviour among their adolescent daughters, as was found in previous studies $(11,21,25-28)$. The brief information that we offered to the parents prior to their making their decision about the vaccine may have changed and increase the likelihood of its acceptance $(13,21,28-33)$. As demonstrated in previous research related to the acceptance of vaccination against STIs (34), the HIV vaccine was the most acceptable of the vaccines presented, given strong public awareness about this disease. The characteristics of the disease and personal experience 

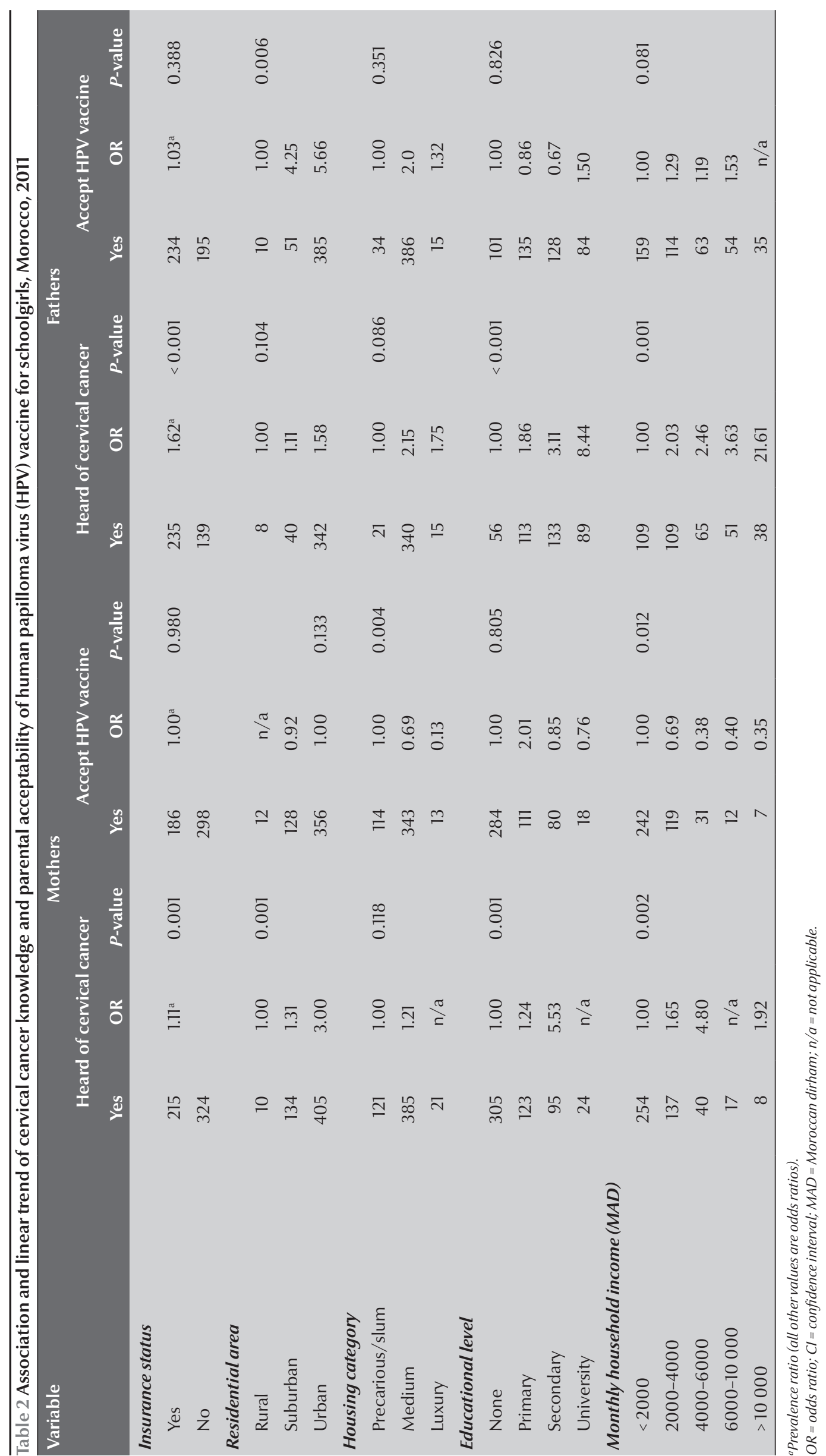


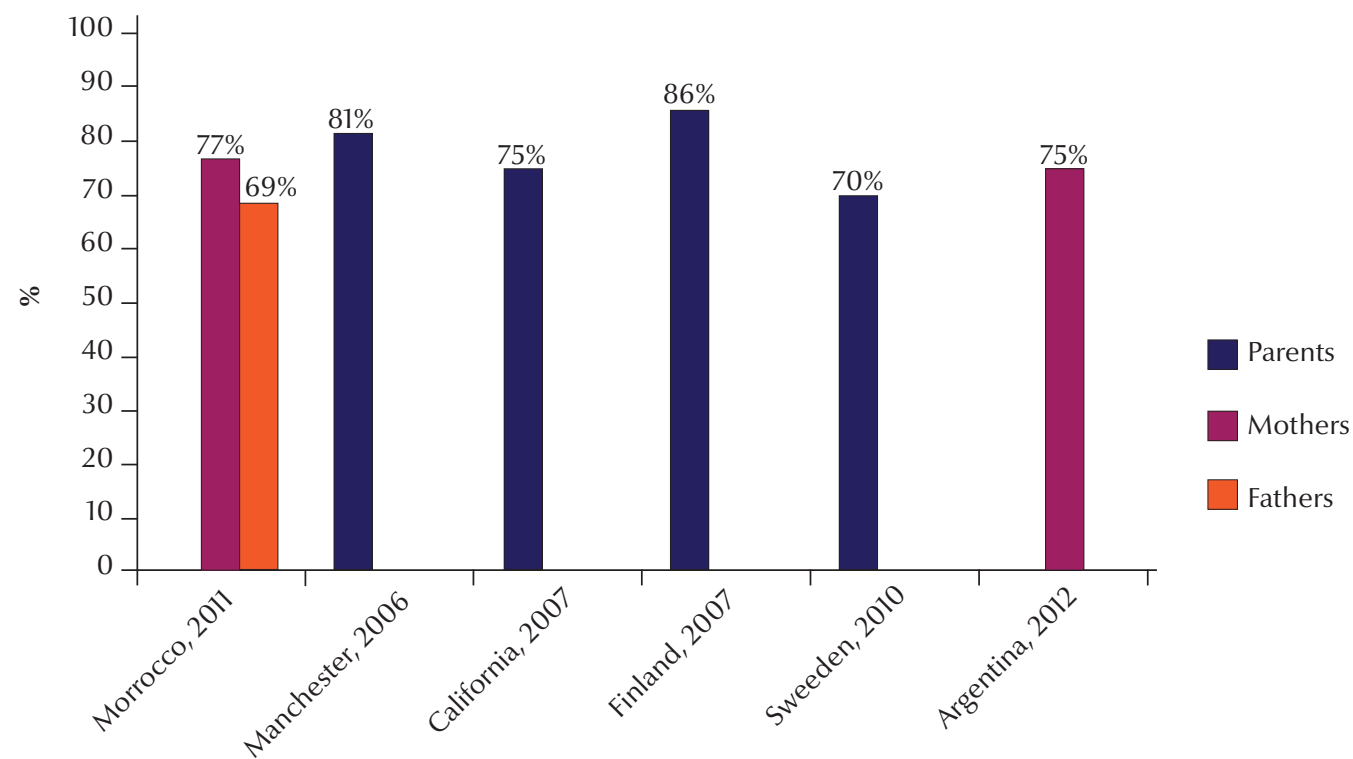

Figure 1 Parental acceptance of the human papilloma virus (HPV) vaccine for their daughters in Morocco and other settings

were also identified as factors influencing parental acceptability of vaccines (34). In our context, the population had a very negative perception with respect to cancer (35). Moroccans assume that cancer is an incurable fatal disease and this could be behind the high acceptability rate of the HPV vaccine among Moroccan parents.

The cost of the HPV vaccine could be a barrier to parents having their daughters vaccinated. Efforts are needed to negotiate the price with laboratories, especially for middle-income countries such as Morocco which are excluded from the GAVI alliance.

The great majority of Moroccan parents supported administration of the vaccine for girls between the ages of 13 and 18 years. This is probably linked to the lack of knowledge of parents about cervical cancer and the HPV vaccine, as there is evidence that it is better to be vaccinated between the ages of 9 and 13 years. Alternatively they may be mainly concerned about the health of their young daughters (15).

The participation rate was very high for both parents. Our study design, using 2 independent samples of mothers and fathers, gave us an unbiased estimation of the parents' acceptance of the HPV vaccine. Some socioeconomic data of our sample was similar to the national data from the Haut Commissariat au Plan survey in Morocco; illiteracy rates among women and men were $50.8 \%$ and $28 \%$ respectively in 2009 and the average monthly income was $5308 \mathrm{MAD}$ in 2007. For the insurance affiliation survey, $44.4 \%$ of women were affiliated compared with $29.1 \%$ of men in 2011 (36). The representative sample of parents recruited in this study might allow for the generalization of the results to all parents in our country. The results will be important in order for policy-makers to prepare for introduction of the HPV vaccine into the immunization schedule as a public health programme. However, if the new HPV vaccines are expected to significantly reduce the incidence of cervical cancer, they will not replace national cervical cancer screening programmes. A comprehensive approach which uses vaccination as well as screening will certainly maximize effectiveness in preventing cervical cancer.

In conclusion, the findings of the presentstudyemphasize theimportance of focusing efforts to improve public awareness about HPV infection and the HPV vaccine by establishing a strong communication strategy and introducing the HPV vaccine into the national immunization programme. For future research, it will be useful to assess predictors that may influence public's acceptability of the HPV vaccine.

\section{Acknowledgements}

We would like to thank Dr Gregory D. Zimet, Indiana University Department of Paediatrics, for his generous and valuable advice, and for the very helpful documentation. We would also like to thank all parents for their participation in the study.

Funding: This investigation was supported by GSK for the benefit of the Eastern Mediterranean Regional Alliance of NGOs against cancer (EMRA). The funding body had no role in the design, the collection, analysis and interpretation of data; in the writing of the manuscript; or in the decision to submit the manuscript for publication.

Competing interests: None declared. 
References

1. Rapport du registre du Grand Casablanca année 2005-2007. Casablanca: Fondation Lalla Salma Prévention et Traitement des Cancers; 2012.

2. GLOBOCAN 2012 database [Internet]. Geneva: International Agency for Research on Cancer, World Health Organization (http://globocan.iarc.fr/ accessed 18 June 2015).

3. Berraho M, Obtel M, Bendahhou K, Zidouh A, Errihani H, Benider A, et al. Sociodemographic factors and delay in the diagnosis of cervical cancer in Morocco. Pan Afr Med J. 2012;12:14. PMID:22826738

4. Chaouki N, Bosch FX, Muñoz N, Meijer CJLM, El Gueddari B, El Ghazi A, et al. The viral origin of cervical cancer in Rabat, Morocco. Int J Cancer. 1998 Feb 9;75(4):546-54. PMID:9466654

5. Harper DM, Franco EL, Wheeler C, Ferris DG, Jenkins D, Schuind A, et al.; GlaxoSmithKline HPV Vaccine Study Group. Efficacy of a bivalent L1 virus-like particle vaccine in prevention of infection with human papillomavirus types 16 and 18 in young women: a randomised controlled trial. Lancet. 2004 Nov 13-19;364(9447):1757-65. PMID:15541448

6. Koutsky LA, Harper DM. Chapter 13: Current findings from prophylactic HPV vaccine trials. Vaccine. 2006 Aug 31; 24 Suppl 3:S3/114-21.

7. FUTURE II Study Group. Quadrivalent vaccine against human papillomavirus to prevent high-grade cervical lesions. N Engl J Med. 2007 May 10;356(19):1915-27. PMID:17494925

8. La Torre G, de Waure C, Chiaradia G, Mannocci A, Ricciardi W. HPV vaccine efficacy in preventing persistent cervical HPV infection: a systematic review and meta-analysis. Vaccine. 2007 Dec 5;25(50):8352-8. PMID:17996990

9. Garland SM, Hernández-Avila M, Wheeler CM, Pérez G, Harper DM, Leodolter S, et al.; Females United to Unilaterally Reduce Endo/Ectocervical Disease (FUTURE) I Investigators. Quadrivalent vaccine against human papillomavirus to prevent anogenital diseases. N Engl J Med. 2007 May 10;356(19):1928-43. PMID:17494926

10. Joura EA, Leodolter S, Hernández-Avila M, Wheeler CM, Pérez G, Koutsky LA, et al. Efficacy of a quadrivalent prophylactic human papillomavirus (types 6, 11, 16, and 18) L1 virus-like-particle vaccine against high-grade vulval and vaginal lesions: a combined analysis of three randomised clinical trials. Lancet. 2007 May 19;369(9574):1693-702. PMID:17512854

11. Colomer MC. Vacuna contra el virus de papiloma humano. Prevenir el cáncer de útero. Offarm. 2008;27(6):112-4

12. Constantine NA, Jerman P. Acceptance of human papillomavirus vaccination among Californian parents of daughters: a representative statewide analysis. J Adolesc Health. 2007 Feb;40(2):108-15. PMID:17259050

13. Marlow LA, Waller J, Wardle J. Parental attitudes to pre-pubertal HPV vaccination. Vaccine. 2007 Mar 1;25(11):1945-52. PMID:17284337

14. Brewer NT, Fazekas KI. Predictors of HPV vaccine acceptability: a theory-informed, systematic review. Prev Med. 2007 Aug-Sep;45(2-3):107-14. PMID:17628649

15. Bair RM, Mays RM, Sturm LA, Zimet GD. Acceptability of the human papillomavirus vaccine among Latina mothers. J Pediatr Adolesc Gynecol. 2008 Dec;21(6):329-34. PMID:19064226

16. Herzog TJ, Huh WK, Downs LS, Smith JS, Monk BJ. Initial lessons learned in HPV vaccination. Gynecol Oncol. 2008 May;109(2) Suppl:S4-11. PMID:18482557

17. Davis K, Dickman ED, Ferris D, Dias JK. Human papillomavirus vaccine acceptability among parents of 10- to 15-year-old adolescents. J Low Genit Tract Dis. 2004 Jul;8(3):188-94. PMID:15874862

18. Kahn JA. Rosen thai SL, HAmann T, Bernstein DI, Attitudes towards human papillomavirus in young women. Int J STD AIDS. 2003;14:300-6. PMID:12803935

19. Waller J, McCaffery K, Nazroo J, Wardle J. Making sense of information about HPV in cervical screening: a qualitative study. Br J Cancer. 2005 Jan 31;92(2):265-70. PMID:15655553

20. Di Giuseppe G, Abbate R, Liguori G, Albano L, Angelillo IF. Human papillomavirus and vaccination: knowledge, attitudes, and behavioural intention in adolescents and young women in Italy. Br J Cancer. 2008 Jul 22;99(2):225-9. PMID:18628763

21. Brabin L, Roberts SA, Farzaneh F, Kitchener HC. Future acceptance of adolescent human papillomavirus vaccination: a survey of parental attitudes. Vaccine. $2006 \mathrm{Apr}$ 12;24(16):3087-94. PMID:16500736

22. Arrossi S, Maceira V, Paolino M, Sankaranarayanan R. Acceptability and uptake of HPV vaccine in Argentina before its inclusion in the immunization program: a population-based survey. Vaccine. 2012 Mar23;30(14):2467-74. PMID:22266289

23. Dahlstrom LA, Tran TN, Lundholm C, Young C, Sundstrom $\mathrm{K}$, Sparen P. Attitudes to HPV vaccination among parents of children aged 12-15 years-a population-based survey in Sweden. International Journal of Cancer. Journal International du Cancer. 2010;126:500-7. PMID:19569173

24. Woodhall SC, Lehtinen M, Verho T, Huhtala H, Hokkanen M, Kosunen E. Anticipated acceptance of HPV vaccination at the baseline of implementation: a survey of parental and adolescent knowledge and attitudes in Finland. J Adolesc Health. 2007 May;40(5):466-9. PMID:17448408

25. Vaccines and women: cultural and structural issues for acceptability. Chapter 24. In: Azzam H, Kaljee LM editors. Women's global health and human rights. Burlington (MA): Jones and Bartlett Learning; 2010.

26. Zimet GD, Mays RM, Sturm LA, Ravert AA, Perkins SM, Juliar BE. Parental attitudes about sexually transmitted infection vaccination for their adolescent children. Arch Pediatr Adolesc Med. 2005 Feb;159(2):132-7. PMID:15699306

27. Zimet GD, Perkins SM, Sturm LA, Bair RM, Juliar BE, Mays RM. Predictors of STI vaccine acceptability among parents and their adolescent children. J Adolesc Health. 2005 Sep;37(3):179-86. PMID:16109336

28. Coleman MA, Levison J, Sangi-Haghpeykar H. HPV vaccine acceptability in Ghana, West Africa. Vaccine. 2011 May 23;29(23):3945-50. PMID:21481327

29. Moraros J, Bird Y, Barney DD, King SC, Banegas M, Suarez-Toriello E. A Pilot Study: HPV Infection Knowledge \& HPV Vaccine Acceptance among Women Residing in Ciudad Juárez, México. Calif J Health Promot. 2006;4(3):177-86.

30. Lee PW, Kwan TT, Tam KF, Chan KK, Young PM, Lo SS, et al. Beliefs about cervical cancer and human papillomavirus (HPV) and acceptability of HPV vaccination among Chinese women in Hong Kong. Prev Med. 2007 Aug-Sep;45(2-3):130-4. PMID:17707077

31. Baykal C, Al A, Uğur MG, Cetinkaya N, Attar R, Arioglu P. Knowledge and interest of Turkish women about cervical cancer and HPV vaccine. Eur J Gynaecol Oncol. 2008;29(1):76-9. PMID:18386470

32. Walsh CD, Gera A, Shah M, Sharma A, Powell JE, Wilson S. Public knowledge and attitudes towards human papilloma virus (HPV) vaccination. BMC Public Health. 2008;8:368. PMID:18947430 
33. Poole DN, Tracy JK, Levitz L, Rochas M, Sangare K, Yekta S, et al. A cross-sectional study to assess HPV knowledge and HPV vaccine acceptability in Mali. PLoS One. 2013;8(2):e56402. PMID:23431375

34. Mays RM, Sturm LA, Zimet GD. Parental perspectives on vaccinating children against sexually transmitted infections. Soc Sci Med. 2004 Apr;58(7):1405-13. PMID:14759685
35. Connaissances, perceptions et attitudes à l'égard du cancer : étude quantitative et qualitative. Analyse de la situation. Volume 5. Rabat, Maroc: Association Lalla Salma de lutte contre le cancer; 2009. pp 125-49.

36. Les indicateurs sociaux du Maroc en 2011. Rabat, Maroc: Haut Commissariat au Plan; 2011 